\author{
Krystyna BRZOZOWSKA, Professor \\ Faculty of Management and Economics of Services, University of Szczecin \\ e-mail: krystyna.brzozowska@wzieu.pl \\ ORCID: 0000-0003-1205-4332
}

DOI: $10.15290 /$ oes.2018.03.93.03

\title{
FINANCIAL STRUCTURE OF LOCAL GOVERNMENT PROJECTS IN POLAND AND GLOBAL TRENDS
}

\begin{abstract}
Summary
The aim of the paper is to analyse and evaluate the financial structure of local infrastructure projects in Poland, divided into types of local governments, as compared with the financial structure of both global and European infrastructure projects. The research is based on secondary data from statistics published by specialised periodicals and agencies, as well as on data included in budget implementation reports published on the website of the Ministry of Finance. The analysis covers the financial structures of infrastructure projects on the global and European scale in the years 2015, and in Poland in the years 2015-2016.
\end{abstract}

Keywords: financial structure, infrastructure project, world, Europe, Poland, local governments

JEL classification: E22, F34, F65, G2, H54

\section{Introduction}

Infrastructure investments are an indicator of a prosperous economy, one which provides a basis for further development and implementation of innovations in the broad sense of the word. Public authorities are responsible for ensuring access to efficient infrastructure, adjusted to the needs of society. However, high capital intensity of infrastructure facilities and networks, on the one hand, and tight budgets, on the other hand, make infrastructural gaps difficult, or even impossible, to close.

Infrastructural needs keep increasing despite the growing number of investments. It is estimated that infrastructural deficiencies on a global scale have reached the level of approx. $\$ 0.7$ billion. Investment needs in highly developed countries (both in the European Union and the United States) result chiefly from the necessity to modernise infrastructure, whereas in less developed countries they stem from the need to construct new facilities and networks [Arezki et al., 2016, p. 7]. However, it should be remembered that the problem of insufficient financial resources for covering the costs of infrastructure investments affects mainly projects at the global, continental, strategic, and national level. Smaller, regional or local, investments are at 
less risk of failing to be brought to financial closure. However, this does not mean that minor investments in infrastructure do not face other difficulties, e.g., those connected with selecting appropriate financing structure or planning the order in which particular strategic investments are implemented. Irrespective of the size of investment and its importance for the economic growth of a region or country, each public infrastructure project must address the question of choosing financing sources and neutralising the risk connected with their application.

The aim of the paper is to analyse the structure of infrastructure project financing in Poland with division into types of local government units, as compared with the structure of financing infrastructure investments in the world. The research was conducted on the basis of secondary data: statistical data published by specialised journals and agencies, and (in the case of Poland) data included in the reports on implementation the budgets of local government units, published on the website of the Ministry of Finance.

\section{Structure of funding public projects}

Investment projects can be financed from an investor's own funds or other resources (usually debt) or from a mixture of an organisation's own and borrowed funds. In practice, the most frequently used form of financing is the mixed one (the third option), because financing of particularly capital intensive infrastructure investments from own (public) funds is impossible owing to the tight budgets and inadequate budget surpluses. Additionally, when analysing the possibilities of funding an investment, all the potential creditors take into consideration the value of the potential debtor's own contribution and require a minimum level of own funds.

To bring an infrastructure project to financial closure requires time-absorbing consultations, negotiations, detailed calculations with all the creditors, the financial involvement of whom creates the structure of project financing, i.e. the proportions of various funding sources necessary to cover all the investment costs.

The structure of financing infrastructure projects is characterised by:

- a high degree of debt in relation to the estimated cost of investment (from $50 \%$ to $90 \%$ of the estimated value of a project),

- $\quad$ an insufficient number of pledged assets,

- dependence of the credit period on the development of the country - the less developed a country, the shorter the credit periods, whereas the higher its rating, the longer the credit periods,

- a correlation between the degree of public support and the country's rating - in countries of lower financial standing and at lower stages of economic growth, public authorities tend to give more support to infrastructure investments,

- the use of foreign funds in the form of international credits granted by international financial organisations as well as in the form of aid measures offered mainly by the European Union - the lower the economic develop- 
ment of a country, the greater the chance of obtaining funds from these sources.

The structure of financing investments is an issue which usually takes the longest to resolve [Kwiatkowski, 1998, p. 98]. The financing conditions are of key importance for the future liquidity of the debtor, i.e. the ability to meet current commitments, and even solvency. It should be kept in mind that the interests of the negotiating parties are divergent by nature, especially with reference to such issues as credit period, the price of debt securities (interest rate plus commissions) and, above all, the ratio of the debtor's own funds to repayable funds.

\section{Financial instruments used for funding infrastructure investments}

The basic source of financing infrastructure projects (apart from capital injections from public partners in the form of in-kind contributions and budget and private surpluses in the form of shares or stocks) are loans taken from commercial banks. The most frequently used credits for financing public investment projects include term loans, open-end credits, stand-by credits, and bridging loans.

Another important group of debt instruments are credits offered by such multilateral financial institutions as the World Bank Group, the European Investment Bank, the European Bank of Development and Reconstruction, the Asian Development Bank, the African Development Bank, the Inter-American Development Bank, or the Caribbean Development Bank.

Credits offered by commercial banks and multilateral financial institutions for covering the costs of infrastructure projects constitute a major part of all the debt incurred in financial markets. Banks have become one of the main participants and, at the same time, decision-makers in investment processes. Their position gives them the right to control and supervise the development of projects. It could even be argued that banks are second in significance only to public authorities.

Other forms of financing (such as issuing bonds, stocks, or equity shares) are of much smaller, although growing, importance in the international financial market. The remaining capital market instruments, i.e. financial derivatives (interest rate swaps, currency swaps, and options) are in fact hedging instruments.

The financing of infrastructure projects by means of debt securities is developing at a relatively dynamic rate. What appears to be the disadvantage of bonds from the perspective of the structure of financing an infrastructure project are the excessively long intervals between the purchase of bonds and the obtainment of funds from their emission. The main advantage of bonds over credits is the possibility of attracting larger groups of investors. Additionally, the emission of bonds is characterised by lower interest rates, considerable flexibility, and the opportunity to promote the issuer. The costs of issuing bonds as a form of long-term debt are particularly high for small entities. For large organisations, the emission of bonds is virtually standard practice whose costs are relatively low in comparison with the value of the generated turnover [Grinblatt, Titman, 1998, p. 15]. In the market, there are mainly 
bonds that are listed in the public market - such as municipal bonds, eurobonds, treasury bonds, revenue bonds, and circular bonds. Bonds can be mono-currency or multicurrency instruments, with variable interest rates, zero coupon instruments, with deferred payment of interest, convertible, warranted, etc. Municipal bonds are more popular in all highly developed countries. However, in the United States they definitely play the largest role among the instruments of financing infrastructure investments. In developing countries, municipal bonds are slow to enter the market for two major reasons: the lack of experience and tradition in the issue of commercial papers and the lack of appropriate legal frameworks and implementing rules.

Equity investments in infrastructure involve subscribing to stocks and shares in public-private partnership projects. They account for 15 to $30 \%$ of the estimated value of an investment [Songer, Dickmann, Pecsok, 1997, p. 378] and their size determines the value of debt which creditors are prepared to grant for financing a project. The type of private capital depends chiefly on the project's objectives, the financial capacity of their owners, their inclination to make long-term investments, and their ability to obtain tax preferences. The basic types of equity investments include stock capital or share capital in the form of cash shares paid in certain time periods, development capital in the form of shares of developers received by way of remuneration for services rendered, in-kind contributions, subordinated debt, or convertible debt in the form of mezzanine financing [Bull, Lethbridge, 1996, p. 291]. In recent years, an increasing role is played by infrastructure funds, which are private equity investment funds. Infrastructure funds rely on infrastructure assets, which they acquire with revenue from the sale of units to investors [Davis, 2008]. The purpose of infrastructure funds is to ensure medium- and long-term capital through investing in capital instruments or structured investment products of entities involved in the development of infrastructure. Infrastructure funds usually invest for 5-8 years. Their units are typically bought by other funds, insurance companies, private and public pension funds, government institutions, and property management companies. Most of the largest infrastructure funds operate in developed countries - in Europe and North America - and are sponsored by large financial institutions. More than $55 \%$ of infrastructure funds established over the last few years are sponsored by banks. Participation of infrastructure funds in financing infrastructure investments is regarded as private financing from funds listed on the public market as well as unlisted funds.

Other financing sources such as stock issues, are of much smaller importance in the international financial market, although their role is increasing. The remaining capital market instruments, i.e. financial derivatives (interest rate swaps, currency swaps, and options) are in fact hedging instruments.

\section{Structure of financing infrastructure investments in the world}

The value of global infrastructure investments in 2017 amounted to $\$ 905 \mathrm{bn}$, having increased by more than $\$ 57$ bn as compared with 2016. In the recent years, 
the dynamics of changes in the value of implemented infrastructure investments on a global scale has not been particularly high - from 14\% in 2012 to $7 \%$ in 2017 , in comparison with the preceding year (see chart 1). Nevertheless, over the last 6 years, some positive dynamics has been observed, which is evidence of a systematic increase in the value of infrastructure investments. In 2017, the level of dynamics decreased in comparison with the year 2016, but the number of realized projects increased by $22.4 \%$. Therefore, in 2017 more investments were realized, although less costly ones. The average value of one project decreased from $\$ 546$ bn USD in 2016 to $\$ 477 \mathrm{mn}$ in 2017 [Global, 2017].

CHART 1

Value of infrastructure investments on global scale

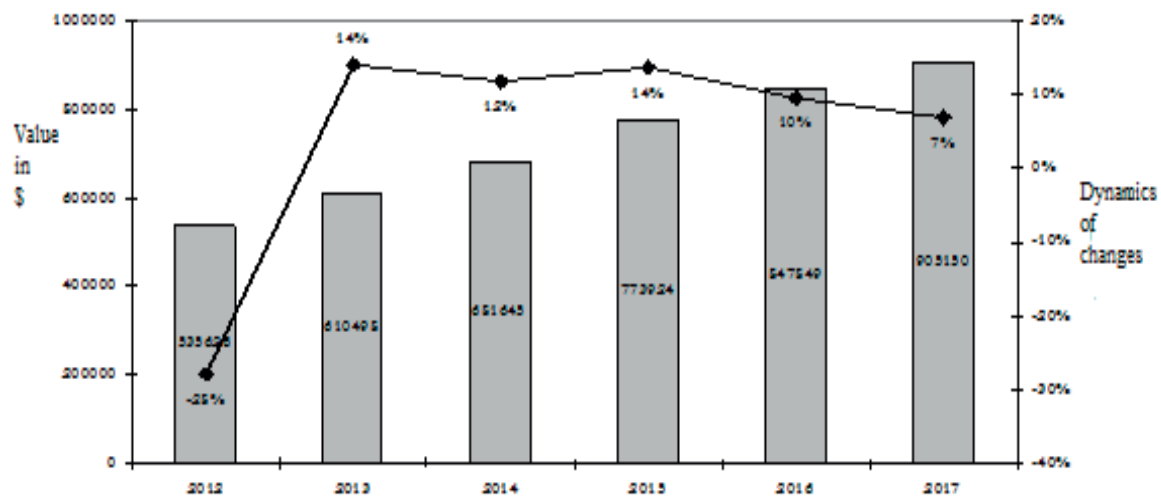

Source: [Global Infrastructure Finance, 2017].

Chart 2 presents the structure of financing global infrastructure investments. It should be noted that the item "credits of multilateral financial institutions" also includes the value of subsidies received from public authorities. The financing structure in general was dominated by credits, the total share of which (bank credits and credits from multilateral financial institutions) in the years 2015-2017 ranged from $42.5 \%$ in the first half of 2017 to approx. 63\% in 2015.

Taking into consideration the average share of particular sources in the analysed years, it can be assumed that the financing structure in $42 \%$ consisted of bank credits, in $29 \%$ of equity instruments, $19 \%$ of bonds, and in $10 \%$ of credits from multilateral financial institutions. Therefore, it can be concluded that a change has taken place in the proportions of financing infrastructure investments at the global level. The share of bonds remains steady, whereas the share of bank credits is decreasing relatively fast in favour of equity instruments. This is a result of the impact of two factors: rapid development of the market of infrastructure funds and their expansionist policy, as well as an increasing importance of private equity (public-private partnership) projects. 
CHART 2

Structure of financing infrastructure investments on a global scale in the years 2015-2017

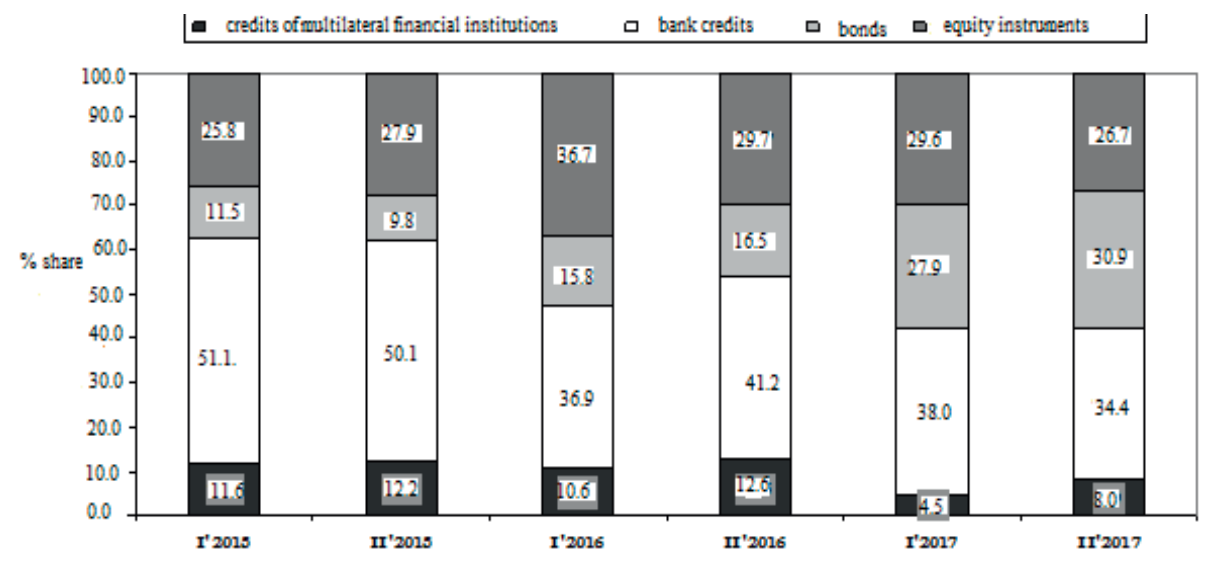

Source: author's own work on the basis of [Global, 2016, 2017].

\section{Structure of financing infrastructure investments in Europe}

Infrastructure investments implemented in Europe account for more than 30\% of the value of the portfolio of investments worldwide. In 2017, the value of infrastructure investments in Europe amounted to more than $\$ 281$ bn, and was $\$ 28$ bn lower than in 2016, whereas the number of investments rose: from 649 in 2016 to 778 in 2017. The average value of an investment was lower than the global average, amounting to $\$ 477 \mathrm{mn}$ in 2016 and $\$ 362$ USD in 2017.

CHART 3

Value of infrastructure investments in Europe in years 2015-2017

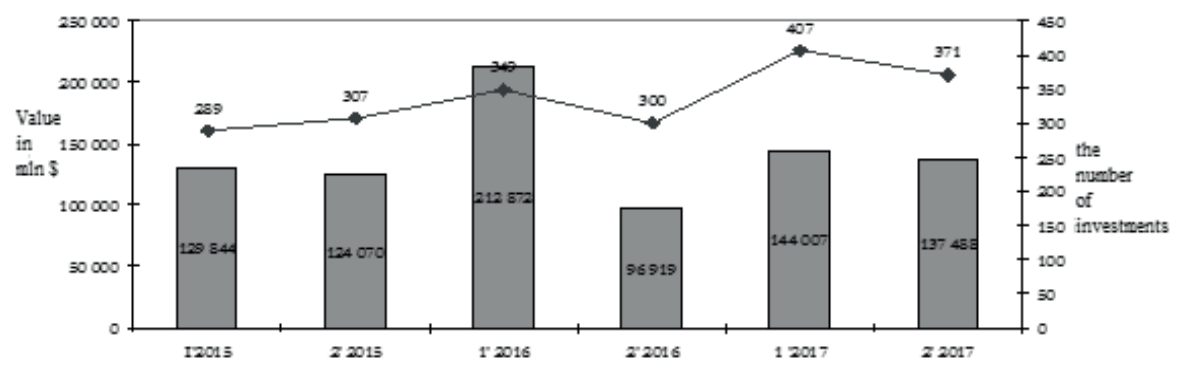

Source: [Global, 2016, 2017]. 
Chart 4 presents the structure of financing infrastructure investments in Europe in the years 2015-2017. Similarly to infrastructure investments on a global scale, bank credits were the most common source of financing, although their share was observed to be decreasing.

CHART 4

\section{Structure of financing infrastructure investments in Europe in years 2015-2017}

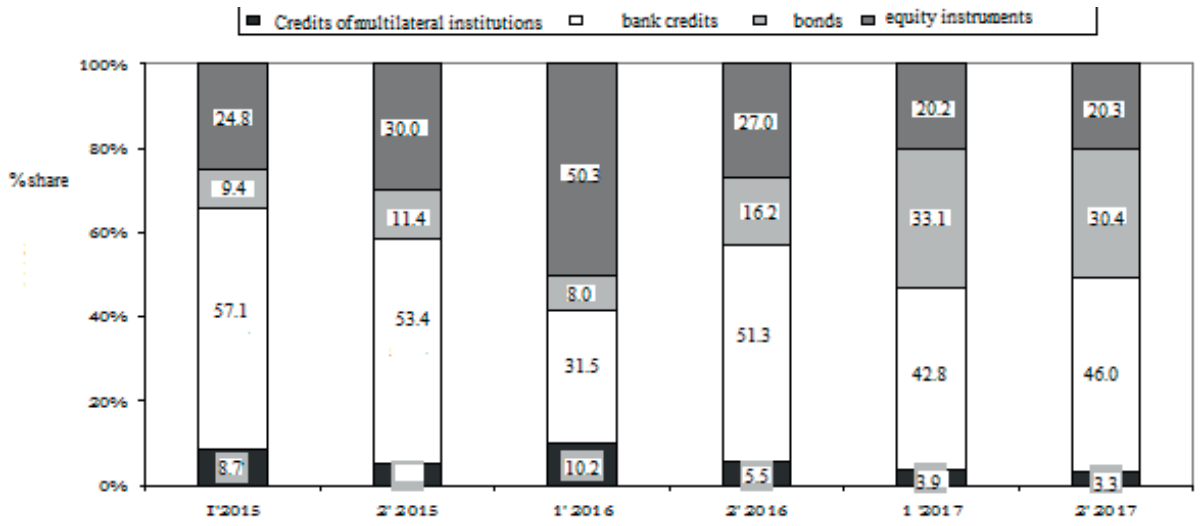

Source: author's own work on the basis of [Global, 2016, 2017].

In the structure of financing infrastructure investments in Europe, the share of credits offered by multilateral financial institutions was far lower than globally, which may be explained by the significance of global investments carried out in Africa, South America, etc. for multilateral financial institutions, such as the World Bank Group. Especially worthy of note is the increased share of bonds (reflected in the structure of financing investments worldwide), caused chiefly by the issue of green bonds and "green" treasury bonds worth a total of \$10.7 bn USD ( $९ .7$ bn in the issuing currency) in France in 2017, for the first time on such a scale [Green, 2018]. The high share of equity instruments, similar to the global average, can be explained by vigorous development of the market of public-private partnership in Great Britain (on a smaller scale in France, Spain, Italy, and Germany) and of the market of infrastructure funds.

The research of the European Investment Bank, on a sample of selected local government units in EU countries in terms of infrastructure investments implemented over the last 5 years, adopts a different perspective of financing sources. Selected results (including those regarding Poland) are presented in Chart 5.

When analysing the structure of financing infrastructure investments of local government units, a distinction was made between LGUs' own resources (financial surpluses they achieved and repayable funding sources such as credits and loans) and private equity shares, investment subsidies, support from the EU structural 
funds referred to as external financing, as well as funds from the issue of municipal bonds.

LGUs' own resources had the highest share in financing the investments - on the scale of the EU, France and Great Britain - it oscillated around 50\%, in the case of Germany $-40 \%$, whereas in Poland $-70 \%$. Poland was also the most substantial beneficiary of EU funds, besides Benelux countries. As regards using debt securities, in Poland their share was the lowest among the selected European countries - approx. $5 \%$.

CHART 5

Sources of financing infrastructure investments of local government units in Europe

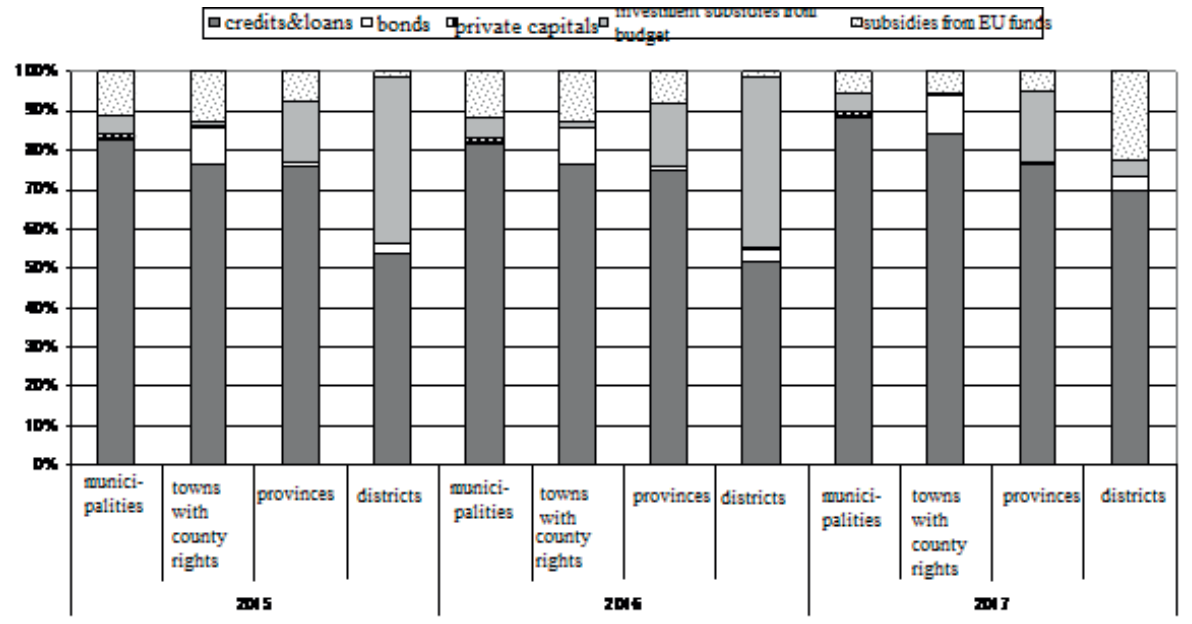

Source: author's own work on the basis of [EIB Group, 2018].

Further study will concern the verification of the research conducted by Infrastructure Journal and the European Investment Bank and regarding local government units in Poland.

\section{Structure of financing infrastructure investment of local governments in Poland}

The statistical data for the research were obtained from the reports on implementation of the state budget for the years 2015-2017, including Informacje o wykonaniu budizetón jednostek samorzadu terytorialnego [Informacja, 2016; Informacja, 2017; Informacja, 2018]. The analysis concerned the sources of financing infrastructure investments with division into investment subsidies, credits, loans, and bonds. 
Investment subsidies were divided into two groups: subsidies from the state budget and subsidies from EU programmes. Particular attention was paid to investment subsidies:

- for government administration tasks,

- for LGUs' own tasks,

- for tasks realized on the basis of agreements between LGUs,

- from aid distributed among LGUs for financing their own tasks,

- obtained from special funds,

- $\quad$ related to programmes partly financed by the EU, with the exception of the subsidies mentioned in paragraphs 200 and 620 ,

- from programmes partly financed by the European Union in the financial perspective 2014-2020, excluding the subsidies mentioned in paragraphs 205 and 625 .

The last two groups regard investment funds obtained by local government units from EU funds.

The data concerning credits and loans for investment purposes are expressed as total amounts. It proved impossible to obtain data with division into credits given by commercial banks and by development (multilateral) banks.

The data concerning the issue of bonds are also expressed as total amounts, without division into municipal bonds, Catalyst bonds, and revenue bonds.

The data concerning private capital involved in financing infrastructure investments come from the database of PPP projects published on the website of PPP Platform (www.ppp.gov.pl). The estimated value of the project was adopted as private capital, in line with the description of the involvement of private partner included in the PPP Platform database. The research comprised projects for which implementation contracts had already been signed in the years 2015 and 2016.

The research regarded the types of local government units. The time range of the research covered two years: 2015-2017. The choice of this period was correlated with the data concerning the world and Europe. The structure of financing infrastructure investments at the level of local government units differs from the global and European ones (chart 5). It coincides, however, with the results of the research conducted by the European Investment Bank. A detailed analysis of a purely comparative character was conducted for the period of the last 3 years. The main source of financing public investments at the level of LGUs were credits and loans: from more than $80 \%$ in municipalities to above $50 \%$ in voivodeships. An important source of financing public investments were also investment subsidies from the state budget, in particular for counties and voivodeships. It can also be observed that the main beneficiaries of the EU funds were towns with county rights (share of 10\%) and municipalities (approx. 5-10\%).

The share of other financial instruments (bonds, private capitals) in the structure of financing local government investments was not higher than $10 \%$, and despite differences between years, the largest share of other instruments regarded towns with county rights. The use of equity instruments in the form of stocks and shares 
was negligent. Greater involvement of private capital was observed in investments made in municipalities in the years 2015-2017.

CHART 6

Structure of financing infrastructure investments in Poland in years 2015-2016 with division into types of LGUs

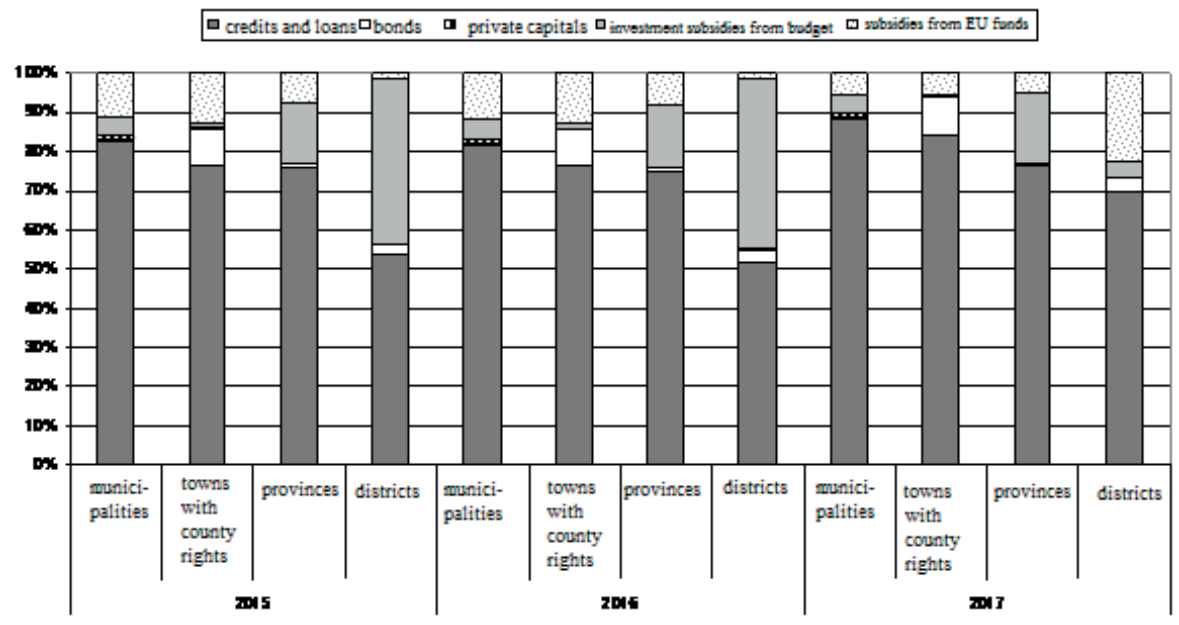

Source: author's own work on the basis of [Informacja, 2016; Informacja, 2017; Bazy, 2017].

What needs to be emphasised is the extremely limited use of bonds and private capital in financing local government investments. In general, public-private partnership projects ${ }^{1}$ were implemented exclusively in towns with county rights and municipalities (in 2016, one PPP project was implemented at a district level - the construction of a new courthouse in Nowy Sącz). Additionally, municipalities and towns with county rights availed themselves of the possibility to finance investments through the issue of bonds ${ }^{2}$.

The presented data (although they should be treated as merely illustrative since the research period is too short to draw any authoritative conclusions) clearly show that as long as local governments have a relatively easy access to EU funds, returnable loans and equity investments will be not be widely applied. When EU programmes are no longer available, local governments will be forced to seek other financial instruments (with the exception of subsidies), such as credits (at present, LGUs use mainly credits, but usually only bridging ones, regarded as ad-hoc measures before EU subsidies are obtained), bonds, private equities within the framework of PPP projects, as well as infrastructure funds.

\footnotetext{
On this subject see [Brzozowska, 2017].

2 On this subject see [Brzozowska et al., 2018].
} 
The market of returnable and equity instruments will develop, and local governments will be more active in seeking financing sources in order to close financial gaps because, as it is estimated, investment needs related to public infrastructure are unlikely to decrease; on the contrary - they will probably increase. Additionally, it should be remembered that experience, qualifications and knowledge of the issue of debt securities and public-private partnership will be much greater, which should help overcome stereotypes and change the attitudes of LGU officials into less conservative ones.

\section{Conclusions}

Infrastructure investments are developing at a rapid rate despite their high capital intensity and long implementation periods. Owing to the continually growing needs for infrastructure and increasing infrastructure gap, as confirmed by the research conducted by McKinsey (by 2030, infrastructure needs are expected to reach $\$ 3.3$ bn annually, whereas the present level of investments amounts to $\$ 2.5$ bn annually [Woetzel et al., 2016, pp. 8-9 and Public, 2016]), finding the sources of funding has become a true challenge. The analysis of the presented international data implies that the structure of financing infrastructure investments is changing: the share of credits and loans is shrinking, while the share of equity instruments is rising. The structure of financing public investments in Poland, meanwhile, remains dominated by credits with a relatively lower share of equity instruments than in other European countries. Such a conclusion can be drawn from the research of the European Investment Bank and the author's own research. Returnable and equity financing only serves as supplementary sources.

A change in the proportions of infrastructure investment funding in Poland can take place after the expiry of the EU programmes supporting infrastructure investments, and after the sense and the advantages of equity instruments like bonds and public-private partnership are better understood. The needs regarding the development of infrastructure in Poland by 2030 require the involvement of capital worth PLN 1.5 bn, thus it has become necessary that more private-sector funds, mainly from the capital market are deployed, in line with the position expressed by Polish authorities [Polityka, 2017, pp. 3-4].

\section{References}

Arezki R., Bolton P., Peters S., Samama F., Stiglitz J., 2016, From Global Savings Glut to Financing Infrastructure: The Advent of Investment Plarforms, IMF Working Paper $16 / 18$.

Basy projektón PPP ₹ podpisanymi umowami - czerwiec 2017, http://www.ppp.gov.pl [date of entry: 2.02.2018].

Brzozowska K., 2017, Rozwó́j PPP w Polsce - analiza zaangażowania jednostek samorzadu terytorialnego, „Prace Naukowe UE we Wrocławiu”, nr 485, s. 44-58. 
Brzozowska K., 2018, Determinanty myboru źródet finansowania rozpwoju lokalnego i regionalnego na rynku kapitatonym, [w:] Brzozowska K., Gorzałczyńska-Koczkodaj M., Kogut-Jaworska M. , Szaja M., Finansowe determinanty rozwoju lokalnego i regionalnego, Edu - Libri, Kraków.

Bull R., Lethbridge N., 1996, Using Project Finance to Minimize the State Budget Funding of Essential Infrastructure Emerging Market Economies, [in:] Kirkpatrick C., Weiss J., Cost Benefit Analysis and Project Appraisal in Developing Countries, Edward Elgar, Cheltenham.

Davis K., 2008, Listed Infrastructure Funds: Funding and Financial Management, http:// ssrn.com/abstract+1337473 [date of entry: 9.02.2018].

EIB Group Survey on Investment and Investment Finance 2017. 2018EIB, p. 16.

Global Infrastructure Finance 2016. League Tables, http://ijglobal.com [date of entry: 9.02.2018].

Global Infrastructure Finance 2017. League Tables, http://ijglobal.com [date of entry: 9.02.2018].

Green Bond Highlights 2017, 2018 Climate Bonds Iniatiative, www.climatebonds.net [date of entry: 5.02.2018].

Grinblatt M., Titman S., 1998, Financial Markets and Corporate Strategy, Irwin/McGraw - Hill.

Informacja o wykonaniu budżetów jednostek samorz̨adu terytorialnego, 2015 http://www.mf. gov.pl/ministerstwo-finansow/dzialalnosc/finanse-publiczne/budzety-jednostek-samorzadu-terytorialnego/sprawozdania-budzetowe [date of entry: 9.02.2018]

Informacja o wykonaniu budǐetón jednostek samorzadu terytorialnego, 2016 http://www.mf. gov.pl/ministerstwo-finansow/dzialalnosc/finanse-publiczne/budzety-jednostek-samorzadu-terytorialnego/sprawozdania-budzetowe [date of entry: 9.02.2018]

Informacja o wykonaniu budżetów jednostek samorz̨adu terytorialnego, 2017 http://www.mf. gov.pl/ministerstwo-finansow/dzialalnosc/finanse-publiczne/budzety-jednostek -samorzadu-terytorialnego/sprawozdania-budzetowe [date of entry: 9.02.2018]

Kwiatkowski P., 1998, Ogólny system zabezpieczeń mykorzystywanych prayy kredytowaniu przedsiewrieć inwestycyjnych na zasadach project finance, „Bank i Kredyt”, nr 7-8.

Polityka Rzqdu w zakeresie rozzwoju partnerstwa publiczno-prywatnego - załącznik do uchwały nr 116/2017 Rady Ministrów z dnia 26 lipca 2017 [Annex to Act no. 116/2017 of the Council of Ministers of 26 July 2017] (RM-111-83-17).

Public Works, sector by sector 2016 Salini Impregilo Digital Magazine, https://www. webuildvalue.com/en/infrastructures/puplic-works-sect [date of entry: 25.02.2018].

Songer A.D., Diekmann J., Pecsok R.S., 1997, Risk. Analysis for Revenue Dependent Infrastructure Projects, "Construction Management and Economics", vol. 15.

Woetzel J., Garemo N., Mischke J., Hjerpe M., Palter R., 2016, Bridging Global Infrastructure Gaps, McKinsey Global Institute.

www.ppp.gov.pl 